Sole agency vs. multi-agency: an investigation of agency practice across England and Wales

April, 2009

Qiulin Ke

Nottingham Trent University, School of Architecture, Design and Built Environment, Burton Street, Nottingham, UK, NG1 4BU

Email: qiulin.ke@ntu.ac.uk

Tel: 44 (0)115 8482381

Fax: 44(0)115 8486140

Michael Jayne

Nottingham Trent University, School of Architecture, Design and Built Environment, Burton Street, Nottingham, UK, NG1 4BU

Email : michael.jayne@ntu.ac.uk

Tel :0044 (0) 1158482173

Fax: 44(0)115 8486140

David Isaac

The University of Greenwich, School of Architecture and Construction, Avery Hill Campus, Bexley Road, Eltham, London, UK, SE9 2PQ

Email: d.isaac@gre.ac.uk 
Sole agency vs. multi-agency: an investigation of agency practice across England and Wales

\begin{abstract}
Purposes: This paper investigates the impact of different agency practice on agency fees, business efficiency and housing market liquidity.

Design/methodology/approach - The paper studies the effect of sole and multiple agency practices on estate agent efficiency, housing market liquidity and commission fee levels. The analysis uses the survey data from 2000 to 2006 to investigate the different agency practices across England and Wales and their effect on estate agency business efficiency, housing market liquidity, selling price and fee levels.
\end{abstract}

Findings - The empirical analysis confirms that agency practice has a locality bias, that is, some regions are more likely to adopt sole agency practice than other regions. The estate agents with a sole agency practice charge a lower agency fee, help clients to achieve better selling price and are more efficient; whereas multiple agency practice facilitates liquidity in the housing market, but experiences higher fall-through rate.

Research limitations/implication - The research focuses on estate agent rather than consumers due to the limitation of the data based on a research project concerning transaction costs designed prior to this analysis.

Originality/value - There is little other research that investigates the residential estate agency practice and its impact on housing market in the past three decades in England and Wales. The findings are a useful guide for practitioners to better understand the issues associated with different agency practices and should enhance business efficiency and performance. 
Key words - Sole agency, Multiple agency, Efficiency, Selling price, Liquidity, Fee Paper type - Research paper

\section{Sole agency vs. multi-agency: an investigation of agency practice across England and Wales}

\section{Introduction}

In the UK, estate agency is primarily governed by The Estate Agents Act 1979 as amended by legislation such as the Consumer, Estate Agents and Redress Act 2007. There is no legal requirement directing any particular method of sale, such as multiple or sole agency but there are legal duties imposed upon the agent. Some of these may have an impact on the sales process. These include the 'Duty of Care' which requires the estate agent to 'do their best' for their client. If sale is by sole selling rights or sole agency, the agent must explain their meaning, or amended meaning, as set out in The Estate agency guide (OFT 2008). There is a legal duty to promptly give written details of all offers received from potential buyers (except where a client has given permission for them not to be passed on) and it is illegal to discriminate against potential buyers because they might not want to take services from the agent's firm or business connections.

For no clearly defined reason, two different types of agency for property disposal have developed in Britain. 'Sole agency' as a method of operating in the property market means that only one agent is appointed to act for the vendor. In referring to sole agency 
areas one is referring to those parts of the country where this is the normal practice. 'Multiple agency' or 'mixed agency' has been used to describe the practice, mainly common in the south of the country, where vendors may instruct more than one agent, and often several, each to act independently of the other(s), with only the successful agent receiving the commission. Multiple agency areas could better be described as 'mixed agency' areas, for some vendors within them do choose to instruct only one agent to act for them in a sole agency capacity, normally for an agreed period of time. The main sources of research addressing the various agency practices in Britain are to be found in the report conducted by the Monopolies Commission (1969) and subsequent survey by the Centre for Advanced Land Use Studies (CALUS) in 1975. It would appear that since then, there has been a paucity of published research in this field. Consequently this is a subject that warrants greater study.

In 1969, the Monopolies Commission published their report which found that estate agency practice varied in Britain and, although the pattern was not regular, north of a line drawn roughly from the Wash to the Bristol Channel, sole agency was the generally accepted method of operating (see Figure 1). South of this line, multiple agency was the general rule, for although some vendors chose to appoint a firm of estate agents to act as their sole agents in the disposal of a property, many would instruct more than one and in some cases several. This practice was generally accepted by the agents - not only accepted as normal practice but accepted on the basis that only the agent who ultimately succeeded would receive commission. The report put forward one possible reason for such a distribution of different agency practice, that is: " there is some ground for 
thinking that in this respect the north and the south are at different points in a historical development of the practice of estate agency..., the north has not reached this point [multiple agency]" (cited in Stephens, 1981, pp.83).

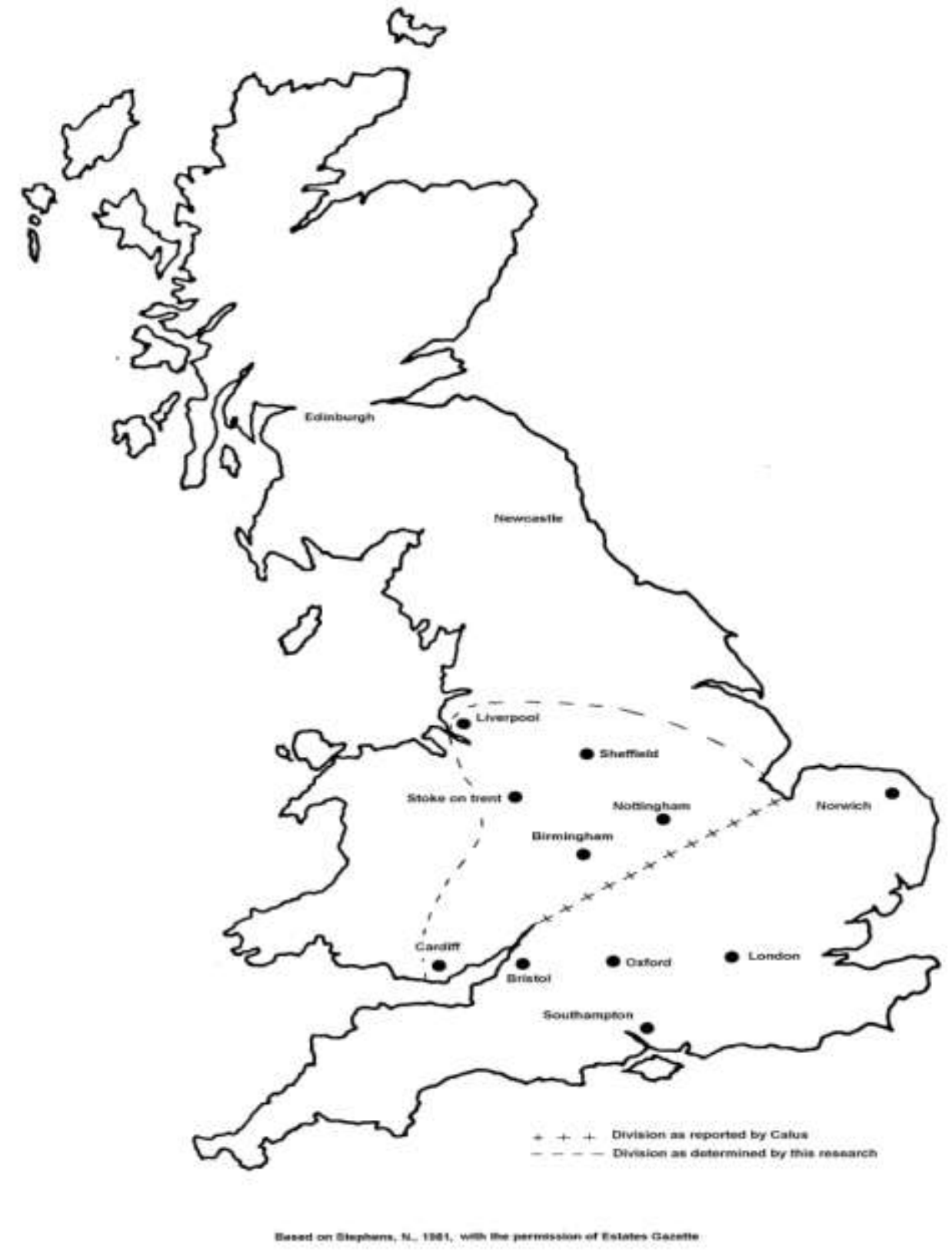

Figure 1 
In 1975, the Centre for Advanced Land Use Studies carried out research and published its findings. They reported that the location of the firms that took part in the survey and the nature of agency practice had not changed significantly over the six years since the 1969 Monopolies Commission report. The regions that primarily undertook sole agency practice were Newcastle, Keighley, Liverpool, Sheffield, Lincoln, Stoke-on-Trent, Birmingham, Nottingham, Leicester, Norwich and their surrounding areas, reflecting regional difference in practice (Stephens, 1981, pp.84).

In terms of income and net profit generated by the agents in the North and the South, the report compared the average commission per sale and the average profit in the two areas and found very little difference in net profit. In the incidence of abortive work, the agents in the South sold only one house out of every five for which they received instructions, whilst the Northern agents sold three out of every four. There were various explanations as to how the two different forms of practice arose. It has been suggested that the explosion in home-ownership occurred earlier in the South and that it had been much more extensive. Northern communities were more self-contained and house-buyers less likely to move from one area to another and at less frequent intervals; the high level of movement in the South provided a much wider market for the agents to exploit. In addition, the general level of house-value in the North tended to be lower than those in the South and, significantly, commission rates also were historically lower. As a result, not only might the market place have been smaller but the rewards disproportionately 
less. These factors may have acted as a deterrent to the acceptance, by agents, of multiple agency form of practice (Stephen, 1981).

Since the CALUS (1975) report, there has been little research addressing this topic even though the housing market has been through several recessions and recoveries in the intervening period. It would seem reasonable to deduce that the changes which have occurred to the housing market during this thirty-year period would have influenced the use of sole and multiple agency practices, to a greater or lesser extent, since there is an intrinsic connection between the housing market and the estate agency industry.

The research utilises the data collected from the Moving Cost Survey conducted by Woolwich Plc. in conjunction with the University of Greenwich. This survey had been conducted every year since 1987 to 2006 and was designed to look at the trends of moving-cost changes in the residential property market across England and Wales. For each survey, the questionnaires were posted to a randomly selected sample of estate agents across the UK. Respondents from the previous year would participate in the next year's survey by receiving the questionnaire again and new samples would be added in the following year's survey.

The responding agents were not asked directly whether they used sole agency practice or multiple agency practice since this was not the primary objective of the survey. However, they were asked to provide the fee levels charged for sole agency or/and multiple agency, if applicable. Firms with multiple agency practice would provide two types of 
information, in contrast with those operating sole agency practice only. This differentiation was used as a basis for distinguishing the data in order to undertake this research. For consistency and convenience of analysis, the study period covers seven years, from 2000 to 2006 while the study range covers 10 different regions (i.e. East Anglia, East Midlands, Greater London, North, North West, South East, South West, Wales, West Midlands and York \& Humber) across England and Wales, comprising 558 towns and cities. Scotland was excluded from the analysis since Scottish agents use a different form of practice.

In this paper, Section 2 reviews the literature, whilst Section 3 defines the data and research methodology. Section 4 discusses the results of test. The conclusions and research limitations are discussed in Section 5.

\section{Literature review}

A review of the literature revealed that there are few studies on estate agency practice and its impact on the efficiency of estate agents and housing market in the UK.

According to Stephens (1981), the advantages of sole agency practice are as follows:

- It eliminates much abortive work, reduces costs and encourages agents to charge commission at a lower rate.

- It creates a better and more professional relationship between vendor and agent, in that it imposes on that agent an obligation to use his best endeavours to carry out 
his instructions and removes from him any temptation there may be to give anything other than the soundest possible advice.

- In buoyant market conditions it minimises the tendency on the part of vendors to "gazump".

Disadvantages could be considered as follows:

- The time taken by a sole agent to conclude a sale may be longer. In the multiple agency areas, the agent receiving instructions knows that it is the vendor's intention to instruct other agents, thus the agent would ensure that the property details or particulars will be sent to prospective purchasers as quickly as possible. The sole agent would be more able to put such work off.

- Although the sole agents will recognise their duty to obtain the maximum possible price for their client, that client only has one agent's judgement of value on which to rely.

However, multiple agency also has advantages. The vendor instructing more than one agent will obtain greater exposure, because no one agent will be in contact with all prospective purchasers in his area. From a purchaser's viewpoint, a visit to any one agent is likely to give him, if not a comprehensive list of the properties available in that area, at least a fuller one than he would probably get if sole agency was the generally accepted practice in that region. 
Against this, multiple agency practice generates abortive work and cost. The agent may be reluctant to spend money on promoting a sale if he knows that his money might be wasted, should another agent find a buyer first and so get the commission (Stephens, 1981).

A different agency practice system is adopted in the U.S. A. where the agency relationship between agent and seller is formalized in the listing contract and there are several types of listing arrangements. Under an Open Listing (similar to multiple agency in the U.K), the seller can list the property with multiple agents and is liable to pay commission only to the agent that procures the sale. The seller does not pay any commission if he finds the buyer himself. Under Exclusive Agency listing, the contracting agent shall be the only (exclusive) agent that will be entitled to a commission and no other agent will have a direct contractual relationship with the seller. The seller alone may sell the property without incurring liability to pay the contracting broker. These two contracts are now rarely used in residential markets in the U.S under Multiple Listing Services (MLS) system (Miceli, 1988). The most common listing arrangement is Exclusive-Right-To-Sell contract which entitles the contractual agent to compensation regardless of who sells the property, including owner or other agents. Unlike the U.K, under the Multiple Listing Services (MLS) system adopted in the U.S, member firms submit their listings to the service, which then distributes the collected information to all other members. Sales arranged by an agent other than the agent who originally acquired the listing result in a sharing of the commission according to a prearranged rule. The MLS is advocated to be advantageous in widening the house information exposure and easing the price competition among agents (Miceli, 1988). 
There are several studies in the U.S context which investigate the impact of contract types on agent performance and the relation of time on market and selling price. They highlight the complexity between list price and time on market (Rutherford, et al. 2001 and 2004; Asabere, et al. 1996; Arnold, 1999; Yavas and Yang, 1995). These findings indicate that a lower listing price is not necessarily related to a shorter time on the market (Arnold, 1999), and higher list prices lead to longer marketing times (Yavas and Yang, 1995). Rutherford, et al. (2001) developed and empirically tested a model that analyzed the effect the type of listing contract had on the performance of the agent. Their study found that exclusive agency listing contract resulted in faster sales and lower price than the exclusive-right-to-sell contract. Rutherford, et al. (2004) further extended their study and looked at difference between housing submarkets delineated by price. Their test results reveal a selling price discount associated with both broker-effected and ownereffected for lower-priced houses compared with exclusive agency. They also offer evidence that shorter marketing times can be achieved without sacrifice of price, particularly for higher-priced house under exclusive agency listing arrangement. Miceli, (1991) examined the impact of split commissions on broker effort in MLS sales. He found that splitting the commission between the listing and finding brokers (when they differ) maximizes the joint profits of brokers. While sellers still prefer to pay only the broker who finds a buyer, brokers may not be willing to acquire and share listings under such an arrangement. 
Regarding the role that an estate agent plays with respect to time on market and selling price, Anglin (1997) identified several variables as being important in explaining buyer behaviour, the estate agent associated with the provision of information being one of these variables. He argued that time on market is largely dependent on the performance of the selling agent, as well as overall market conditions. Judd, et al. (1996) investigated whether the seller's choice of real estate agent influences liquidity. Their study found no evidence that a particular agent or firm is able to sell a property faster than others, a finding, they argued, is consistent with efficient information flow and objectivity of the Multiple Listing Service. Yavas and Yang (1995) suggested that properties listed and sold by the same agency did not sell any more quickly than others with different brokerage arrangement. Baryla, et al. (2000) and Baryla and Zumpano (1995) indicated that the probability of a buyer finding a home increased over time with a broker-assisted search reducing time by increasing the number of properties viewed.

When comparing agency service systems in the U.S and U.K, Miceli, (1988) attributed these differences to (1) the government role in the industry and (2) the level of owneroccupier which is substantially higher in the U.S. In the U.S, the real estate agency industry is regulated by the government through licensing, whilst this is not the case in the U.K. These research findings, though biased towards the U.S market, may have certain underlying comparability within the sales process to enable them to have validity in the UK situation.

\section{Data definition and research methodology}




\section{Research methodology}

The data were selected from the Moving Cost Survey conducted by Woolwich Plc. in conjunction with the University of Greenwich. Due to a large number of estate agents participating in the survey over the study period, the data available for this analysis was sufficient and only the respondents providing full information were used for analysis, resulting in 4731 usable observations. The descriptive statistics test and mean comparison are undertaken to test the differences caused by different agency practices in terms of business performance, business efficiency, market liquidity and agency fees. Due to the nature of the survey questions, a Likert type scale technique was used to process the data and determine the respondent's level of agreement to a particular statement in order to undertake the analysis. This technique is used to capture subjective opinions numerically, allowing the researcher to collate quantitative data.

\section{Data definition}

Based on the research objectives defined, i.e. to investigate the impact of different agency practices on commission fee, business efficiency and housing market liquidity. The following questions on the survey questionnaire were determined as being appropriate for this research purpose. Table 1 summarizes the criteria of Likert scales of the study variables.

- The firm size (Size). The size of estate agents is represented by the number of outlets in the organization to which a particular office belongs. To measure the 
firm's size, respondents were asked to detail the number of outlets in their organization.

- Business growth level (Business Level): the question asking agents to indicate percentage of change in business level in the past 12 months is used as representative of business performance; an increase in business level indicating growth and vice versa. It is argued that multiple agency practice would increase abortive work and reduce efficiency and business performance as well.

- New instruction (New instruction): the percentage change in receiving new instructions over the past 12 months. This variable should be treated with caution. A positive change in new instructions for multi-agency does not necessarily mean a positive change in new business, since the vendor can instruct more than one agent to act in multiple agency practice and only the one affecting a sale will get the commission. However, for sole-agency, this would indicate a positive change, that is an increase in the number of new instructions.

- How close the final selling price is to the asking price (How close). Agents were asked to indicate how much of the asking price can be achieved. Empirical studies in the U.S context suggest that types of agency contract can have an impact on the final selling price (Rutherford, et al., 2001 and 2004). Where a vendor puts a property on the market for sale through more than one agent, the negotiation power of a prospective purchaser may be increased; therefore, the final selling price achieved through multiple agency may be lower than the asking price. A sole agent is more likely to help the vendor to attain the asking price or even higher. 
- Most active sector (Active sector): agents were asked to indicate the most active housing price bands in their regions to reflect the nature of their local housing markets. Multiple agency is more likely to be used by agents when dealing with higher value property or in regions where house prices are higher. Consequently this question was used to examine the relation between property value and the choice of agency type as well as a proxy for the nature of the local housing market.

- The time a property is put onto the market (Time on market) is used to determine the relative liquidity. If multiple agency is superior to sole agency in terms of speed, multiple agency will shorten the time required to complete a sale transaction; that is property will be longer on the market if sole agency is used than multiple agency. A larger variable mean indicates the property is exposed to the market for a longer time.

- Purchase fallthrough (Purchase fallthrough): the percentage of purchase fallthrough is used to test the efficiency of different forms of practice. In the U.K. prior to the formal exchange of contracts, the vendor and/or purchaser can withdraw from the transaction process without paying penalty which results in purchase fallthrough. The high purchase fallthrough rate is generally regarded as low efficiency of the agency system or a particular agent.

Table 1 . The summary of study variables in Likert scales

\begin{tabular}{|l|l|l|l|l|}
\hline Variables & \multicolumn{3}{|c|}{ Likert-scales } \\
\hline Size & $\begin{array}{l}\text { Single } \\
\text { practice=1 }\end{array}$ & 2-4 outlets=2 & 5-9 outlets=3 & $10-20$ outlets=4 \\
\cline { 2 - 5 } & $\begin{array}{l}\text { More than } 20 \\
\text { outlets=5 }\end{array}$ & & & \\
\hline
\end{tabular}




\begin{tabular}{|c|c|c|c|c|}
\hline \multirow{2}{*}{$\begin{array}{l}\text { Business } \\
\text { growth level }\end{array}$} & Down $>10 \%=1$ & Down $5-9 \%=2$ & Down $0-4 \%=3$ & Same $=4$ \\
\hline & Up $0-4 \%=5$ & Up 5-9\%=6 & $\mathrm{Up}>10 \%=7$ & \\
\hline \multirow{2}{*}{$\begin{array}{l}\text { New } \\
\text { instruction }\end{array}$} & Down $>10 \%=1$ & Down $5-9 \%=2$ & Down $0-4 \%=3$ & Same $=4$ \\
\hline & Up $0-4 \%=5$ & Up 5-9\%=6 & $\mathrm{Up}>10 \%=7$ & \\
\hline \multirow{2}{*}{$\begin{array}{l}\text { Time on } \\
\text { market }\end{array}$} & $<2$ weeks $=1$ & $2-4$ weeks $=2$ & $4-6$ weeks $=3$ & $6-8$ weeks=4 \\
\hline & $>8$ weeks $=5$ & & & \\
\hline \multirow{2}{*}{$\begin{array}{l}\text { How close to } \\
\text { asking price }\end{array}$} & $<85 \%=1$ & $85-89 \%=2$ & $90-94 \%=3$ & $95-99 \%=4$ \\
\hline & $100 \%=5$ & $101-104 \%=6$ & $>105 \%=7$ & \\
\hline \multirow{2}{*}{$\begin{array}{l}\text { Most active } \\
\text { sector }\end{array}$} & $£ 80 \mathrm{k}-£ 99 \mathrm{k}=1$ & $£ 100 \mathrm{k}-£ 124 \mathrm{k}=2$ & $£ 125 \mathrm{k}-£ 149 \mathrm{k}=3$ & $£ 150 \mathrm{k}-£ 199 \mathrm{k}=4$ \\
\hline & $£ 200 \mathrm{k}-£ 299 \mathrm{k}=5$ & $£ 300 \mathrm{k}-£ 499 \mathrm{k}=6$ & $>£ 499 \mathrm{k}=7$ & \\
\hline \multirow[t]{2}{*}{ Fall through } & $1-5 \%=1$ & $6-10 \%=2$ & $11-15 \%=3$ & $16-20 \%=4$ \\
\hline & $21-25 \%=5$ & $26-30 \%=6$ & $30 \%$ or more $=7$ & \\
\hline
\end{tabular}

4. Test results and analysis

The respondent distribution is reported in Table 2. In total, $3310(76 \%)$ respondents are reported to use multiple agency practice, while 1061 (24\%) use sole agency practice. Multiple agency practice can be seen as being in a dominant position in the UK. Over the study period, about $30 \%$ of respondents replied once, $30 \%$ of them did twice and about $40 \%$ did 3 times or more. It is asserted that this provides reliable and consistent information.

Table 2. The profile of respondents (2000-2006)

\begin{tabular}{|c|c|c|c|c|c|c|c|c|c|c|c|}
\hline Regions & $\begin{array}{l}\text { East } \\
\text { Anglia }\end{array}$ & $\begin{array}{l}\text { East } \\
\text { Midlands }\end{array}$ & $\begin{array}{l}\text { Greater } \\
\text { London }\end{array}$ & North & $\begin{array}{l}\text { North } \\
\text { West }\end{array}$ & $\begin{array}{l}\text { South } \\
\text { East }\end{array}$ & $\begin{array}{l}\text { South } \\
\text { West }\end{array}$ & Wales & $\begin{array}{l}\text { West } \\
\text { Midlands }\end{array}$ & $\begin{array}{l}\text { York \& } \\
\text { Humber }\end{array}$ & Total \\
\hline $\begin{array}{l}\text { No. of } \\
\text { respondents }\end{array}$ & 266 & 271 & 304 & 173 & 260 & 1143 & 1195 & 234 & 275 & 250 & 4371 \\
\hline $\begin{array}{l}\text { towns } \\
\text { Response }\end{array}$ & 26 & 34 & & 30 & 39 & 189 & 98 & 49 & 50 & 43 & 558 \\
\hline $\begin{array}{l}\text { once } \\
\text { Response }\end{array}$ & 62 & 64 & 129 & 47 & 101 & 357 & 313 & 57 & 102 & 65 & 1297 \\
\hline $\begin{array}{l}\text { twice } \\
\text { Response }\end{array}$ & 73 & 96 & 98 & 61 & 76 & 397 & 273 & 66 & 105 & 82 & 1327 \\
\hline $\begin{array}{l}3 \text { times or } \\
\text { more } \\
\text { Mutiple- }\end{array}$ & 105 & 111 & 77 & 65 & 83 & 399 & 609 & 111 & 68 & 103 & 1731 \\
\hline $\begin{array}{l}\text { agency } \\
\text { Sole }\end{array}$ & 237 & 135 & 289 & 68 & 73 & 1028 & 1079 & 167 & 175 & 64 & 3310 \\
\hline $\begin{array}{l}\text { Agency } \\
\% \text { of sole }\end{array}$ & 29 & 136 & 15 & 105 & 187 & 120 & 116 & 67 & 100 & 186 & 1061 \\
\hline agency & $11 \%$ & $50 \%$ & $5 \%$ & $61 \%$ & $72 \%$ & $11 \%$ & $10 \%$ & $29 \%$ & $36 \%$ & $74 \%$ & $24 \%$ \\
\hline
\end{tabular}


Multiple agency practice is not the only form of practice in the South, since a certain number of estate agents, such as 5\% of respondents in Greater London, $11 \%$ in South East and 10\% in South West, 11\% in East Anglia, 36\% in West Midlands and 29\% in Wales state that they do not take multiple agency, at least for property with relatively low value. Sole agency is more widely accepted in the regions such as East Midlands (50\%), North (61\%), North West (72\%), and York \& Humber (74\%).

Compared with the last survey in 1975 by the Centre for Advanced Land Use Studies, we found that there are now more regions which take multiple agency practice, such as Liverpool, Birmingham, Nottingham, Norwich and Cardiff where sole agency practice was the accepted practice in the 1970s. These have switched to mixed or multiple agency practice now; however, Newcastle, Sheffield and Lincoln remain regions where sole agency is the generally accepted practice.

The descriptive statistics results in Table 3 suggest that most of the responding firms fall into the category of 2, representing 2-4 outlets. However, the firms with multiple agency practice are generally larger than those using sole agency, indicating that small firms are more likely to practice sole agency. There is no evidence showing the significant differences in business growth level and the number of new instructions received between these two types of practice. However, there is evidence for significant differences in terms of how close the eventual selling price achieved compared with the original asking price, the most active property price sector and the time taken to sell a property. It seems 
that sole agency is more likely to be used for lower value property and can help vendor to achieve the asking price.

Table 3. Descriptive statistics and mean comparison tests (England and Wales, 20002006)

\begin{tabular}{llllllll}
\hline Panel A. & Size & $\begin{array}{l}\text { Business } \\
\text { Level }\end{array}$ & $\begin{array}{l}\text { New } \\
\text { instruction }\end{array}$ & $\begin{array}{l}\text { How } \\
\text { close }\end{array}$ & $\begin{array}{l}\text { Active } \\
\text { sector }\end{array}$ & $\begin{array}{l}\text { Time on } \\
\text { market }\end{array}$ & $\begin{array}{l}\text { Purchase } \\
\text { fallthrough }\end{array}$ \\
\hline $\begin{array}{l}\text { Sole agency (SA) } \\
\begin{array}{l}\text { Multi-agency } \\
\text { (MA) }\end{array}\end{array}$ & 2.16 & 5.12 & 3.89 & 3.73 & 2.97 & 4.35 & 2.72 \\
$\begin{array}{l}\text { Difference of } \\
\text { SAAnd MA }\end{array}$ & 2.24 & 5.13 & 3.91 & 3.56 & 3.73 & 4.2 & 3.19 \\
\hline
\end{tabular}

Panel B. Fees for selective property price bands

\begin{tabular}{|c|c|c|c|c|c|c|c|c|c|c|}
\hline & SA£80k & $\begin{array}{l}\text { MA } \\
£ 80 \mathrm{k}\end{array}$ & $\begin{array}{l}\text { SA } \\
£ 100 \mathrm{k}\end{array}$ & $\begin{array}{l}\text { MA } \\
£ 100 \mathrm{k}\end{array}$ & $\begin{array}{l}\text { SA } \\
£ 150 \mathrm{k}\end{array}$ & $\begin{array}{l}\text { MA } \\
£ 150 \mathrm{k}\end{array}$ & SA£200k & $\begin{array}{l}\text { MA } \\
£ 200 \mathrm{k}\end{array}$ & SA£300k & $\begin{array}{l}\text { MA } \\
£ 300 \mathrm{k}\end{array}$ \\
\hline & $£ 1127$ & & $£ 1354$ & & $£ 1905$ & & $£ 2491$ & & $£ 3589$ & \\
\hline & $£ 1335$ & $£ 1916$ & $£ 1618$ & $£ 2361$ & $£ 2320$ & $£ 3404$ & $£ 3025$ & $£ 4458$ & $£ 4394$ & $£ 6510$ \\
\hline $\begin{array}{l}\text { Difference: } \\
\text { SA and MA }\end{array}$ & $(-208.2)^{*}$ & & $(-264.3)^{*}$ & & $(-415.3)^{*}$ & & $(-533.3)^{*}$ & & $(-805)^{*}$ & \\
\hline
\end{tabular}

Note: $1 .{ }^{*}$ stands for significance at $10 \%$ level.

2. The data "Time on market and purchase fallthrough rate" are available for 2005 and 2006 only.

Table 4 reports the ratios of both types of estate agency to the two indicators: 'how close to selling price' and 'time on market'. The results in Table 3 show that the average time on market was about 6-8 weeks or more for both types of agency practice, but soles agency does seem to take a longer time to sell a property. For example, $53 \%$ of sole agents report a sales period of longer than 8 weeks, compared with $44 \%$ of multiple agents; $32 \%$ of sole agents, compared to $35 \%$ of multiple agents take $6-8$ weeks and $13 \%$ of them, compared to $18 \%$ of multiple agents need 4-6 weeks to sell a property (see Table 4).

Table 4. How close to selling price and time on market

\begin{tabular}{lcccccc}
\hline \multicolumn{2}{l}{ A. How close to selling price } & \multicolumn{1}{l}{} & & \\
\hline & More than 105\% & $100-104 \%$ & $100 \%$ & $95-99 \%$ & $90-94 \%$ & $\begin{array}{c}\text { Less than } \\
90 \%\end{array}$ \\
\hline $\begin{array}{l}\text { Sole } \\
\text { agency (\%) }\end{array}$ & $4 \%$ & $4 \%$ & $4 \%$ & $54 \%$ & $23 \%$ & $12 \%$
\end{tabular}


Multiple

agency (\%)

$0.20 \%$

$0.80 \%$

$2.10 \%$

$61 \%$

$25 \%$

$11 \%$

B. Time on market

\begin{tabular}{lcccc} 
& More than 8 weeks & $6-8$ weeks & $4-6$ weeks & Less than 4 weeks \\
\hline Sole agency (\%) & $53 \%$ & $32 \%$ & $13 \%$ & $3 \%$ \\
\hline Multiple agency (\%) & $44 \%$ & $35 \%$ & $18 \%$ & $3 \%$ \\
\hline
\end{tabular}

Regarding how close the final selling price achieved to the asking price, most of the agents fall into the category of $95-99 \%$, but there are significant differences in other categories, indicating that the sole agency is more likely to achieve a higher selling price. For example, the results in Table 4 show that $8 \%$ of sole agents can help a vendor to achieve a selling price above the asking price, whilst only about $1 \%$ of multiple agents manage to achieve it. More multiple agents (97\%) are reported to achieve a discounted selling price for the vendor than sole agents (88\%). Many factors could influence the selling price of a property. However, there are only limited studies investigating the relationship between time on market and selling price in the U.K. A few studies in the U.S context show that a lower listing price is not necessarily related to a shorter time on the market (Arnold, 1999) and that time on the market varies more with spatial location and market conditions than it does with property characteristics (Anglin, et al. 2003). Pryce and Gibb (2006) analysed the time to sale effects in Glasgow housing market and argue that not only does the marketing time have an impact on selling price but that the timing of sale in relation to wider property cycle for that location is crucial. This may have had an influence on the data relating to the time of the actual responses but as this was not an objective of this research, we did not examine the issues here. Nevertheless, the findings here seem to suggest that the type of agency practice can influence market 
liquidity and selling price to a certain extent, given that all other factors being the same. Anglin (1997) further argued that time on market was largely dependent on the performance of the selling agent, as well as overall market conditions. Our findings here support this argument.

Regarding the most active property price sector over the study period, sole agency falls into the category of $£ 125,000-£ 149,000$ price band, whilst the multiple agency falls into the category of $£ 150,000-£ 199,000$ band, indicating the multiple agency practice is more likely to be applied in the transaction of higher value property. As for the purchase fallthrough rate, the sole agency falls into the category of 6-10\%, significantly lower than multiple agency that falls into the category of $11-15 \%$.

These findings suggest that sole agency can help a vendor to obtain a higher selling price, but it takes longer to complete a sale. Multiple agency is more likely to be used when dealing with higher value property, but has a higher fallthrough rate. This evidence would suggest that multiple agency results in more abortive work and may be wasteful in terms of time and cost.

The fee levels charged by agents using multiple agency practice are significantly higher than those for sole agency across most of the property price bands. For the same price band, a vendor will have to pay a higher rate for multiple agencies than when instructing a sole agent. Thus, if the agent is one of those instructed by one vendor, he/she would charge as high as $45 \%$ more over the fee than if acting as a sole agent. 
Higher commission fee levels charged by multiple agency may be one way that the agents compensate for the risk of abortive work caused by multiple agency practice. It might also discourage vendors from seeking more than one agent to act on their behalf.

Sole agency fees are significantly lower than those for multiple agency. This might be explained by the fact that sole agency is less exposed to the risk of purchase fallthrough and its use by estate agents is encouraged.

\section{Conclusions}

From the analysis of the data, it can be concluded that sole agency practice can help vendor to achieve the asking price and its general adoption should lead to lower commission rate being charged.

In sole agency areas an agent is only going to succeed if an adequate number of instructions are received. To draw new instructions the agent has not only to compete effectively in the image presented to the public, but also with the ultimate effectiveness of the services offered. As a result the quality of that service must be the agent's main concern. Agents in multiple agency areas are faced with different circumstances. The sole agent is more likely to compete successfully in terms of service which is mirrored by the endeavours made to help clients to achieve a higher selling price and maintain a lower 
rate of purchase fallthrough. However, the study suggests that the multiple agency is more likely to compete in terms of speed.

Where speed is the main criterion, the attraction for setting a number of agents in competition with each other is obvious. Since agents are in business to make a profit, they will compete to be the first to affect a sale, but will this sale be on the best possible terms for the vendor? The findings here suggest this is not always the case.

It has been argued that multiple agency could be detrimental to the interests of vendor and agent alike. However, there are many estate agents across England and Wales who use multiple agency practice and the number of regions adopting the multiple agency practice has increased over the last thirty years. One of the reasons could be that there are too many estate agents in England and Wales. It is estimated that there are around 21,000 separately owned estate agency offices in England and Wales (Norwood, 2005), who are competing for available instructions, resulting in a greater level of competition in agency industry. Thus some agents have to adopt multiple agency practice to seek more instructions with the attempt to achieve more deals. Expansion of the housing stock is also mirrored by a rise in the number of estate agents' offices and vice versa

The empirical findings here should be explained with some caution. Since $70 \%$ of the respondents responded more than twice over the study period, the findings may be biased to these frequent respondents. The focus of this study is on estate agents benefiting from the availability of a large set of data collected from the estate agents. However, the 
consumers' view of and their satisfaction to different agency practice are not included in this investigation. This can be a future research topic. Nerveless it is asserted that this study provides some guidance to the practitioners and researchers about the agency practice and its impact on business efficiency and effectiveness.

\section{Reference}

Anglin, P. M., (1997), Determinants of buyer search in a housing market, Real Estate Economics, 25, 567-589.

Anglin, P. M., Rutherford, R. and Springer, T. M., (2003), The trade-off between the selling price of residential properties and time-on-the-market: the impact of pricing setting, Journal of Real Estate Finance and Economics, 26:1, 95-111.

Arnold, M. A., (1999), Search, bargaining and optimal asking prices, Real Estate Economics, 27, $453-482$.

Asabere, P.K., Huffman, F. E. and Johnson, R., (1996), Contract expiration and sales price, Journal of Real Estate Finance and Economics, 13,3, 255-262.

Baryla, E. A. and Zumpano, L. V., (1995), Buyer search duration in the residential real estate market: the role of the real estate agent, Journal of Real Estate Research, 10, 1-13. Baryla, E. A., Zumpano, L. V. and Elder, H. W., (2000), An investigation of buyer search in the residential real estate market under different market conditions, Journal of Real Estate Research , 20, 1/2, 75-91.

Judd, G. D., Seaks, T. G. and Winkler, D. T., (1996), Time on the market: the impact of residential brokerage, Journal of Real Estate Research, 12, 3, 447-458. 
Miceli. J. T. (1988), Information costs and the organization of the real estate brokerage industry in the U.S. and Great Britain, AREUEA Journal. 16, 2, 173-188.

Miceli. J. T. (1991), The multiple listing service, commission splits, and broker effort, AREUEA Journal, 19, 4, 548-566.

Norwood, G., (2005), $21^{\text {st }}$ Century Estate Agency, EG books.

OFT (2008) The Estate agency guide, what you need to know if you are engaged in estate agency work, Office of Fair Trading.

Pryce, G. and Gibb, K., (2006), Submarket dynamics of time to sale, Real Estate Economics, 34, 3, 377 -415.

Rutherford, R., Springer, T. and Yavas, A., (2001), The impacts of contract type on broker performance, Real Estate Economics, 29, 3, 389-409.

Rutherford, R., Springer, T. and Yavas, A., (2004), The impact of contract type on broker performance: submarket effects, Journal of Real Estate Research, 1, 26, 3, 277-298. Stephens, N., (1981), The practice of estate agency, The Estates Gazette Limited. Yavas, A., and Yang, S. X., (1995), The strategic role of listing price in marketing real estate: theory and evidence, Real Estate Economics, 23, 3, 347-368. 